Revue Française de Civilisation Britannique

\title{
Making Sense of the Northern Powerhouse
}

Donner du sens à la Northern Powerhouse

\section{Danny MacKinnon}

\section{(2) OpenEdition \\ 1 Journals}

Electronic version

URL: http://journals.openedition.org/rfcb/5497

DOI: $10.4000 / \mathrm{rfcb} .5497$

ISSN: 2429-4373

Publisher

CRECIB - Centre de recherche et d'études en civilisation britannique

\section{Electronic reference}

Danny MacKinnon, « Making Sense of the Northern Powerhouse », Revue Française de Civilisation Britannique [Online], XXV-2 | 2020, Online since 25 May 2020, connection on 27 May 2020. URL : http:// journals.openedition.org/rfcb/5497; DOI : https://doi.org/10.4000/rfcb.5497

This text was automatically generated on 27 May 2020

\section{(c)}

Revue française de civilisation britannique est mis à disposition selon les termes de la licence Creative Commons Attribution - Pas d'Utilisation Commerciale - Pas de Modification 4.0 International. 


\title{
Making Sense of the Northern Powerhouse
}

\author{
Donner du sens à la Northern Powerhouse
}

Danny MacKinnon

\section{Introduction}

On 23 June 2014, the then Chancellor of the Exchequer in the UK government, George Osborne MP, gave a speech at the Museum of Science and Industry in Manchester, in which he called for the creation of a Northern Powerhouse (NPh). According to Osborne, 'modern economics' meant that great Northern cities like Manchester, Leeds and Liverpool were too small to compete individually on the world stage with London and other world cities, resulting in the economy of the North lagging behind the rest of the UK. This prompted his assertion that:

... if we can bring our northern cities closer together - not physically, or in some artificial political construct - but by providing modern transport connections, supporting great science and our universities here, giving more power and control to civic government; then we can create a northern powerhouse with the size, the population, the political and economic clout, to be as strong as any global city. ${ }^{1}$

Launched in response to widening regional inequalities in the UK, the NPh agenda gathered particular momentum in 2015-2016. Essentially a rather 'sizeist' economic narrative closely informed by the new urban economics and the importance of agglomeration and urban scale and density in fostering competitiveness, it sought to pool the strengths of the Northern core cites, principally Manchester, Leeds, Liverpool and Sheffield, as a kind of transformative urban counter-weight to London. As well as attracting widespread political and public attention, the NPh has also triggered 'copycat' initiatives from other regions, most notably the 'Midlands Engine'.

3 The prominence of the NPh agenda reflects the re-emergence of regional inequality as a major political issue in Britain as the effects of the post-2008 economic crisis and associated austerity measures have exposed stark regional disparities, particularly 
between London and the South East and the former industrial areas in the North and Midlands of England. ${ }^{3}$ The NPh gained traction in the context of the wider spatial rebalancing discourse advanced by the Conservative-Liberal Democrat Coalition government between 2010 and 2015, which sought to promote growth in postindustrial regions outside south east England. ${ }^{4}$ Yet regional divisions have been further highlighted by the Brexit vote of 23 June 2016, with many disadvantaged former industrial areas voting 'leave', pointing to a widespread sense of political disenchantment and abandonment, while the core cities of the North voted to remain in the European Union. The Brexit vote also led to the diminution of the NPh, as its leading champion, Osborne, was dismissed as Chancellor by the new Prime Minster, Theresa May.

4 This article aims to assess the nature and wider significance of the NPh concept, considering its evolution and impact since 2014. Whilst of relatively recent origin, it has had a particularly turbulent career, defined by a change of Prime Ministers, the sacking of Osborne, the momentous Brexit vote of 2016 and the subsequent General Election of 2017. The article attempts to make sense of this rather diffuse and fastmoving initiative by asking what the NPh is and how it should be best understood, as well as examining the effects itis having. It argues that the NPh is a spatial economic narrative or 'imaginary' which has gained the support of a wide range of Northern stakeholders, but that its coherence and implementation has been undermined by a lack of national government commitment and leadership since 2016. The research which underpins the article is based on the analysis of over 200 documentary sources, including government policy statement and strategies, policy reviews and consultancy reports, organisational strategies and position papers, over 100 national and regional press articles and blogs, supplemented by 18 semi-structured interviews with key actors from central and local government, Local Enterprise Partnerships (LEPs), business organisations and thinks tanks conducted between March and October 2017.

The remainder of the article is divided into four sections. The next section positions the $\mathrm{NPh}$ within the wider governance of uneven development in England. This is followed by an analysis of origins of the NPh and its political evolution since 2014. The article then discusses the effects of the NPh initiative, focusing on three policy areas where it plays a major role: transport, inward investment promotion and devolution. The final section concludes the article.

\section{Governing Uneven Development in England}

6 Britain now has one of the highest levels of regional inequality of any major European economy (Table 1). According to data from Eurostat, the gap in GDP per head between the richest and poorest regions in the United Kingdom ranked fourth in a sample of 20 EU countries in 2014. ${ }^{5}$ While levels of regional inequality fell somewhat in the postsecond world war period, they have grown since the late 1970s. Regional inequalities accelerated in the 1980s and continued to widen throughout the sustained growth phase of the 1990s and early-to-mid 2000s. By contrast, levels of regional inequality have fallen in several European countries (Table 1).

7 Table 1: Regional imbalance in selected European Union countries: coefficient of variation in regional Gross Domestic Product (GDP) per capita (purchasing power standard (PPS), NUTS-2 regions) 


\begin{tabular}{|l|l|l|l|}
\hline & 1980 & 2001 & 2011 \\
\hline UK & 0.31 & 0.36 & 0.45 \\
\hline Belgium & 0.43 & 0.44 & 0.37 \\
\hline Germany & 0.35 & 0.23 & 0.23 \\
\hline Italy & 0.32 & 0.28 & 0.22 \\
\hline Netherlands & 0.17 & 0.20 & 0.21 \\
\hline France & 0.15 & 0.18 & 0.19 \\
\hline Spain & 0.14 & 0.19 & 0.15 \\
\hline Greece & 0.35 & 0.21 & 0.14 \\
\hline EU-15 & 0.32 & 0.28 & 0.33 \\
\hline
\end{tabular}

8 Source: Martin, R., Pike, A., Tyler P and Gardiner, B. Spatially rebalancing the UK economy: towards a new policy model? Regional Studies 50:2, (2016) pp 342-357. From Cambridge Econometrics, European Union Data Base.

9 The magnitude of regional inequalities in Britain is evident in the levels of nominal GDP per head in 2014. GDP per head is some 2.4 times higher, at $£ 45,000$, in the richest region (London) than in the poorest regions (Wales and North East England), where it is around $£ 18,000$ per head. These regional differences in living standards are underpinned by differences in innovation and skills. Here, the most R\&D intensive region, the East of England, has levels of investment that are four times those of the lowest R\&D intensive region, the North East. ${ }^{6}$ There are also clear regional differences in skills, with the proportion of the workforce with higher-level qualifications being 20 per cent higher in London than Northern Ireland, Yorkshire \& Humber and the North East. These figures demonstrate that the notion of the North-South divide is well grounded in broad regional patterns of inequality, but it should also be noted that such a characterisation is somewhat crude, given that inequalities within regions are often greater than those between them, with London having the highest levels of inequality. ${ }^{7}$

The post-2008 'great recession' and subsequent partial recovery has also had an uneven regional impact, largely reinforcing and widening existing disparities. While all regions experienced a sharp drop in output, this was greatest in poorer regions such as Northern Ireland, Yorkshire \& Humber and the West Midlands (Figure 1). Many of the cities and regions hit hardest were those still affected by the legacy of industrial restructuring and previous recessions, mainly located in the North and Midlands.

11 Figure 1. UK Regions 2011 Gross Value Added (GVA) Per Capita as a Percentage of Their 2007 GVA 


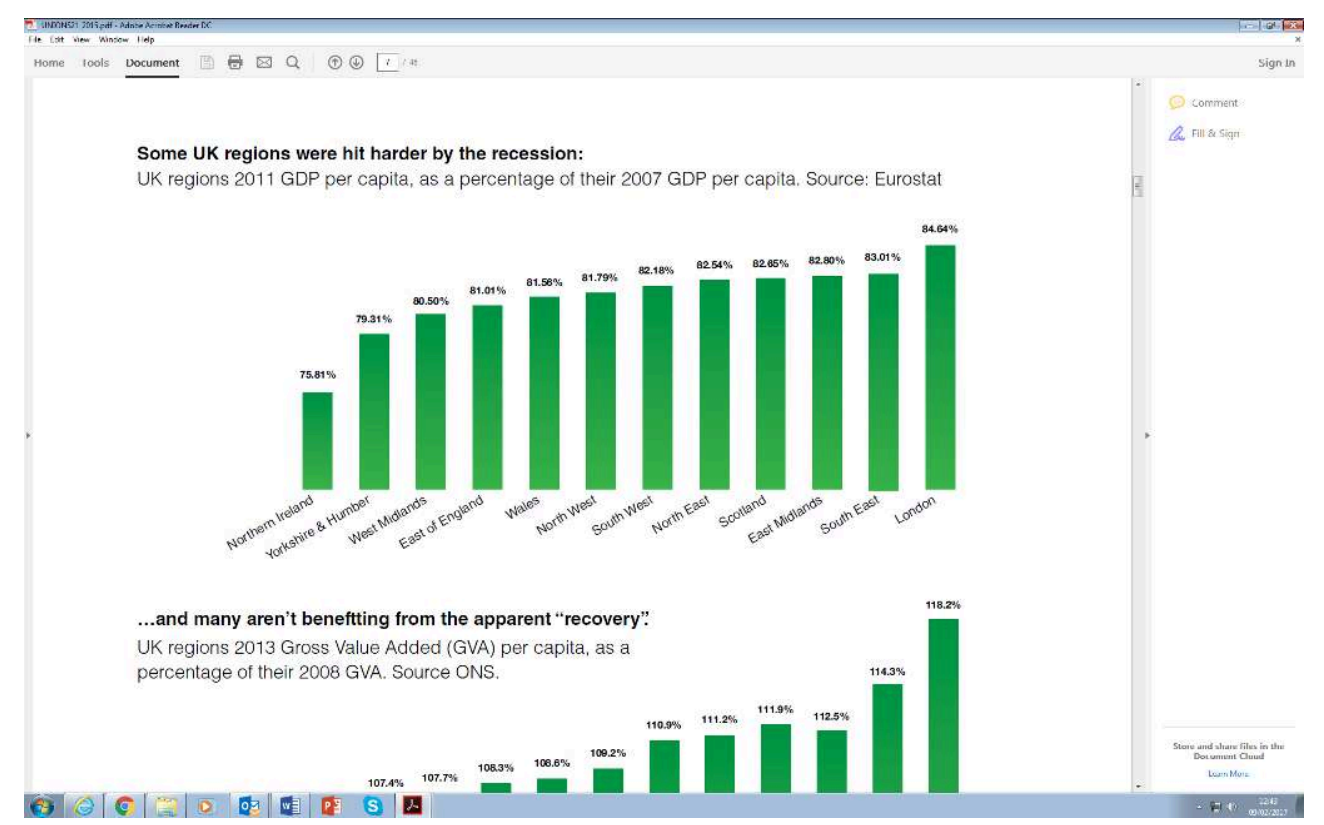

Source: Johnson, Diana “Introduction: tackling Britain's regional inequalities" in Unions 21 Rebalancing the Economy: New Thinking on Tackling Britain's Regional Inequalities. (2015) p.7.

Moreover, the regions have experienced uneven rates of recovery since 2010-2011, with London enjoying the highest rate of growth. The London region experienced a particularly strong economic rebound in 2010-2012, with full-time equivalent employment growing by more than three times the national average. ${ }^{8}$ Growth in private sector employment did resume after 2011 in older industrial parts of Britain, although at lower rate than in London and the South East. ${ }^{9}$ Many of these older industrial areas recorded high 'leave' votes in the Brexit referendum, reflecting a sense of being left behind by globalisation, deindustrialisation and neoliberal economic policies. They are also highly exposed to the consequences of Brexit, however, both in terms of the loss of European regional funding and their dependence upon access to European markets for manufactured goods in particular. ${ }^{10}$

The scale and severity of the regional problem in Britain has been reflected in the introduction of successive policy initiatives designed to address regional inequalities in prosperity and income. The Labour government adopted a new growth-oriented regional policy from 1997, seeking to harness the 'endogenous' potential of all regions, not only the lagging northern ones, but also the prosperous core regions of London and the South East. ${ }^{11}$ The key initiative here was the establishment of Regional Development Agencies (RDAs). The supply-side approach they embodied, however, made little impression on entrenched regional disparities, which widened in the period of sustained national economic growth from the mid-1990s to 2007-2008. ${ }^{12}$

Following the general election of 2010, the new Coalition Government set out its new local growth agenda in its Local Growth White Paper of 2010, which announced the abolition of the RDAs and the establishment of new local growth structures and initiatives. Foremost among these are LEPs, requiring close collaboration between local authorities and business leaders. The creation of 39 LEPs by the end of 2011 created a localised and fragmented geography, and they have been characterised as under- 
resourced and under-powered, despite the allocation of additional finance through the Local Growth Fund from 2015. ${ }^{13}$

The establishment of LEPs and abolition of RDAs was linked to a broader discourse of sectoral and regional rebalancing. This discourse emphasised the need to foster the growth of manufacturing in all regions of the UK so as to counter the over-reliance on financial services in South East England, and sought to promote exports and private investment in areas that had become overly dependent on the public sector. ${ }^{14}$ The key instrument for promoting spatial rebalancing was the Regional Growth Fund (RGF), which aimed to support private sector investment and job creation in areas that were over-dependent on the public sector. ${ }^{15}$ Yet the $£ 3.5$ billion allocated by the RGF between 2011 and 2015 has had little impact on entrenched regional disparities, echoing the RDA experience. Despite the political discourse of regional rebalancing, this lack of impact reflects the continued gap between the scale of the problem of regional inequality in the UK, and the limited level of public resources available to address it. ${ }^{16}$

\section{The Origins and Evolution of the Northern Powerhouse Initiative}

17 In contrast to the localist focus of LEPs, the NPh represents a pan-regional approach for the North, echoing earlier initiatives such as the Northern Way. ${ }^{17}$ While it has been described as both an economic development strategy and a brand or label deployed to "rebadge" existing policies, ${ }^{18}$ this article contends that it is fundamentally a spatial economic narrative or 'imaginary' that constructs the North as a distinct region characterised by economic under-performance relative to London and the South East, political neglect and organisational fragmentation through multiple local authorities and LEPs. The rationale of the NPh is that concentrated investment in transport infrastructure, science and innovation, and skills, together with political empowerment through the devolution of powers to city regions, can address economic underperformance and close the productivity and employment gaps with the rest of the UK. ${ }^{19}$ Reflecting the underlying idea of agglomeration, the NPh is about increasing connections between the core cities of Manchester, Leeds, Liverpool and Sheffield, with recognition of the more geographically distant centres of Hull and Newcastle.

The thinking behind the NPh concept has been influenced by the 'new urban economics' (NUEs) as espoused by economists at the London School of Economics in particular and the Centre for Cities think tank. Exemplified by the writings of the US economist Ed Glaeser, the NUE is part of what Brendan Gleeson calls the 'new urbanology', emanating from North America, which celebrates the economic and social vitality and potential of cities, with a particular focus on urban entrepreneurialism. ${ }^{20}$ In particular, it emphasises the economic benefits generated by the scale and density of economic activity and wealth within cities - agglomeration. In its British variant, the NUEs argues that the geographical agglomeration of economic activity in core cities and region increases national economic growth, as increasing returns and knowledge spill-overs enhance innovation and productivity. Based upon the argument that regional imbalance in the UK is not a reflection of London being too big, but the secondary cities being too small. The solution is to counter-balance London by better integrating and empowering the group of Northern cities, enabling them to act as single agglomeration. ${ }^{21}$ The Royal Society for the encouragement of Arts, Manufactures 
and Science's (RSA) City Growth Commission, was a key source of the NPh concept, espousing agglomeration and recommending a suite of measures to enhance connectivity between Northern cities, boost skills and promote decentralisation. ${ }^{22}$ This thinking fed into Osborne's Manchester speeches which introduced the NPh term..$^{23}$ The RSA Growth Commission was chaired by the former Goldman Sachs investment banker, (Lord) Jim O'Neill, later appointed by Osborne as Commercial Secretary to the Treasury with particular responsibility for the NPh.

While agglomeration and the NUE provided the intellectual rationale for the NPh initiative, what of its political rationale? Most obviously, Osborne was a northern Conservative MP, representing the affluent suburban constituency of Tatton outside Manchester, giving him a direct political and electoral interest in the region. Second, the Conservatives felt the need to develop a regional 'offer' and make electoral gains in the North at the 2015 General Election, with the NPh becoming a central feature of the campaign..$^{24}$ Third, and closely related, it was part of a concerted effort by Osborne and then Prime Minster David Cameron to seize the political centre ground to achieve Conservative hegemony through the appropriation of traditionally Labour issues, thereby wrong footing the opposition. ${ }^{25}$ Fourth, the launch of the NPh initiative can be seen as a response to the widening of regional inequalities that occurred in 2010-2014 as London and the South East recovered faster from the recession, contradicting the government's spatial rebalancing discourse. ${ }^{26}$ The establishment of a new high-profile rebalancing initiative in 2014 should be viewed in the context of the limited impact of existing instruments such as the RGF ${ }^{27}$. Fifth, based on disputed figures produced by the Institute for Public Policy Research (IPPR) North, disparities in infrastructure spending have been widely cited in the media and by Northern political and business leaders, indicating that between 2011-21 and 2015-16, transport spending in London averaged $£ 725$ per head compared to $£ 286$ per head in the North..$^{28}$ This has fed into the case for the NPh with its emphasis on transport investment and connectivity.

Following its establishment in the second half of 2014, the most prominent phase of the $\mathrm{NPh}$ project was between early 2015 and June 2016, reflecting the agreement of devolution deals with core cities, its centrality to the Conservative's 2015 election campaign and a succession of spending announcements on transport, science and innovation and culture. ${ }^{29}$ After the Brexit vote and the fall of Osborne, however, there was real concern over the future of the NPh initiative in view of the new Prime Minister's criticism of the pre-occupation with Manchester and comment on the need to development all of Britain's 'great cities' ${ }^{30}$ In September 2016, Jim O'Neill, resigned from the government, having felt sidelined by the May government after the dismissal of Osborne. ${ }^{31}$ An NPh Minister has remained in place, although this post has had three different occupants since May 2015.

After considerable pressure, the May government publicly affirmed its commitment to the NPh strategy in autumn 2016. It committed itself to building on existing work, with a renewed objective of raising productivity and growth across the North, reflecting suggestions of a more geographically inclusive approach in the wake of Brexit, with more concern for smaller urban centres and rural areas in addition to the core cities, although this more inclusive approach has struggled to gain policy traction in an unstable post-Brexit vote political environment. The Government published a Northern Powerhouse Strategy to coincide with the Autumn Statement of 2016, with a renewed objective of raising productivity and growth across the North, although this is a rather 
low-key and unheralded document that lacks the political profile of earlier statements under Osborne. ${ }^{32}$

\section{Unpacking the Northern Powerhouse: Key Policy Areas}

According to the Autumn Statement of 2014, the NPh initiative had four main elements. ${ }^{33}$ The first, and by far the most significant, is transport..$^{34}$ The second key component is science and innovation, including the new Sir Henry Royce Materials Research Institute (based in Manchester but with branches in Leeds, Liverpool and Sheffield) as well as investments such as a National Innovation Centre for Ageing in Newcastle. The third component is devolution, which in most cases requires the election of so-called 'metro mayors' (see below). The fourth and least significant is culture, which includes a Great Exhibition of the North and funding for a new theatre and exhibition space in Manchester. In what follows, the article focuses on transport, inward investment promotion and devolution as the three most significant areas of on-going impact compared to the rather one-off nature of the science investments announced by Osborne.

\section{Transport Infrastructure Investment}

The overarching NPh vision of bringing the Northern core cities close together into some kind of larger pan-regional agglomeration focuses attention on the need for large-scale transport investment. According to the then Secretary of State for Transport and the Chair of Transport for the North Partnership Board, "a world class transport system must better link up the individual cities and towns in the North, to allow them to function as a single economy and be stronger than the sum of their parts". ${ }^{35}$ The case for transport investment also reflects decades of under-investment in East-West rail links across the Pennines, manifested in basic infrastructure and dated rolling stock, with the notorious 'pacer' trains still in service on some routes. This weakness of these East-West links has been highlighted by the successive government's commitment to the new HS2 link between London, the Midlands, and the North, with Phase 2 consisting of extensions to Manchester and Leeds. A report by the HS2 Chairman, Sir David Higgins, emphasised the scope for improved East-West connections to complement and support HS2. ${ }^{36}$ At the same time, the IPPR figures outlined earlier drew further attention to disparities in infrastructure expenditure between London and the South East and the North. In response, the government announced investments in transport links, including enhanced road capacity, better rail connections and new trains. In total, Neil Lee estimates that around $£ 6.7$ billion of the $£ 7.8$ billion he calculates was allocated to NPh schemes between the Autumn Statement of 2014 and the March 2016 Budget was focused on transport. ${ }^{37}$ Not all of this was new money, however, incorporating funds focused from other spending and existing commitments rebadged as part of the Powerhouse. In any case, the identified $£ 6.7$ billion is less than half of the $£ 14.8$ spent on the Crossrail Scheme in London. ${ }^{38}$

Transport is the one policy area in which the NPh has generated institutional change through the establishment of Transport for the North. TFN emerged out of the government's response to the One North report produced by the leaders of the northern cities in July 2014 in the wake of Osborne's Manchester speech. ${ }^{39}$ As 
chancellor, George Osborne made a commitment in June 2015 to the establishment of $\mathrm{TfN}$ as a statutory transport body for the region by 2017, giving it budget of $£ 10$ million a year until 2020. Its remit is to develop a transport strategy for the north, decide on key priorities and to represent the region to government as a kind of 'single voice'. It is supported by a partnership between Northern local authorities and LEPs, representatives of which sit on its partnership board, with national government and national transport agencies. TfN published its Draft Strategic Transport Plan for public consultation in January 2018 with the final version scheduled for publication later in $2018 .^{40}$ This identifies seven strategic development corridors as the focus for future investment. TfN gained statutory status on 1 at April 2018, which essentially means that government ministers are required to take account of its regional priorities in making national investment decisions. As such, it is not an executive body akin to Transport for London or Transport Scotland, lacking borrowing powers of its own. ${ }^{41}$

The concept of the new line between Manchester and Leeds, dubbed HS3 or Northern Powerhouse Rail, has become central to the broader NPh initiative, following on from HS2 and TfN's work on East-West links. As part of its strategic vision, TfN has developed plans for a new Trans Pennine line between Leeds and Manchester via Bradford, as well as significant upgrades to other parts of the regional rail network. ${ }^{42}$ Yet growing concerns about the government's continued commitment to this project were crystallised by the apparent cancellation of the electrification of the existing transPennine line by Transport Secretary Chris Grayling in July 2017, along with other schemes in the Midlands and Wales, in response to escalating costs of the work being undertaken by Network Rail. This was quickly followed by an expression of support for the Crossrail 2 project in London. ${ }^{43}$ This infuriated Northern leaders, who convened a Northern transport summit in Leeds to demand a rethink. Business leaders also wrote to the government requesting transport investment, whilst a public petition lunched by IPPR gathered 86,431 signatures by 12 September $2017 .{ }^{44}$ This hostile public response prompted hurried visits by the Prime Minster and Chancellor to the region to reassure local leaders of their continued commitment, with the latter meeting with the metro mayors of Greater Manchester, Liverpool and the Tees Valley. ${ }^{45}$

\section{Inward Investment Promotion}

26 The NPh offers scale in the context of increased international competition for investment, allowing the region to pool its strengths to match more closely the scale of sub-regions in continental Europe or Asia. In particular, the scale of the region is considered to be broadly comparable to a Chinese mega-region or mega-city at around 15 million residents, giving it the necessary weight and critical mass in international markets. Here, the name itself is seen as highly attractive to international investors, evoking a sense of large-scale opportunity, based upon the region's long history of innovation, entrepreneurship and commercialisation, stretching back to the industrial revolution of the nineteenth century. ${ }^{46}$

Investment opportunities in the NPh region have been aggregated and packaged in the form of a Northern Powerhouse 'pitchbook' containing some twenty projects seeking capital investment. This 'pitchbook' was first put together in September 2015 in conjunction with a trade mission to Chengdu, China by George Osborne and Jim O'Neill, accompanied by a group of northern core city local leaders. ${ }^{47}$ The trade mission to 
China represents a key moment in the formation of the NPh brand, particularly in term of the receptiveness of the Chinese audience who 'got' the idea straight away, reflecting their own thinking in terms of mega-cities and shifting economic geographies. ${ }^{48} \mathrm{From}$ a UK government, the NPh capital investment portfolio represents part of a wider regional rebalancing agenda, with the UK Trade and Investment (UKTI) Regeneration Investment Organisation given the remit of attracting such investment into Northern projects from 2013. ${ }^{49}$ Manchester has been successful in attracting overseas investment, most notably through the Beijing Construction Engineering Groups' investment in the Airport City' joint investment and the agreement between Manchester city council and the Abu Dhabi United groups - the owners of Manchester City Football Club - to build 6000 new homes in East Manchester.

The emergence of the NPh brand has restored intermediate regional-level inward investment promotion in the North of England following the abolition of the RDAs in 2011, rescaling this from the regional to the pan-regional level. While it remains centralised within the newly created Department for International Trade, inward investment promotion has been coordinated by a dedicated NPh team based in Manchester since 2016. In addition to the attraction of inward investment into the region, this team also encourages Northern firms to move into overseas export markets, undertaking eighteen NPh export missions in 2016. ${ }^{50}$ There is some evidence that the NPh brand is associated with an increasing volume of inward investment as the $\mathrm{NPh}$ region and the Midlands Engine attracted double the number of projects in 2016 that they did in 2007, while the rest of England continues to attract roughly the same number. ${ }^{51}$

\section{Devolution}

The devolution of power and responsibilities to local areas within England has become a major priority for government since 2014, reflecting the wider regional rebalancing agenda and representing a somewhat overdue corrective to the entrenched centralism of the UK state..$^{52}$ Part of the context for this was the Scottish independence referendum of September 2014 which highlighted the glaring gap in devolved powers between Scotland and English localities and regions..$^{53}$ Devolution has subsequently become one of the major components of the NPh initiative, based on the widespread belief that devolution would strengthen the economic performance of Northern city regions. ${ }^{54}$ Combined authorities, established by neighbouring local authorities to address crosscutting issues such as transport and economic development, became the key receiving bodies for devolved powers. Six of the nine combined authorities set up in England by June 2017 were in the North, following the formation of the 'trailblazer' Greater Manchester authority in $2011 .{ }^{55}$ Manchester has also led the way on devolution through the Greater Manchester agreement of November 2014. This grants the city-region extensive powers over transport, planning, housing, police, skills, health and social care. Subsequently, another five devolution deals were agreed with Northern cityregions, namely, Liverpool, Sheffield, Tees Valley and the North East, typically involving more limited powers over skills, employment, transport and housing, in addition to five deals with other parts of the country. ${ }^{56}$ establishment of directly elected mayors as a condition of devolution deals. Elections 
for these directly elected 'metro mayors' were held in six areas on 4 May 2017, including Greater Manchester, the Liverpool City Region and Tees Valley. The devolution process ran into difficulties in other areas, however, particularly the North East and Yorkshire. In the North East, the devolution deal collapsed after four of seven local authorities rejected it, although a reduced 'North of the Tyne deal' was announced in November 2017 for the three authorities that supported devolution. In Yorkshire, 18 local authorities and the key business organisations have come together in support of a 'One Yorkshire' deal for the region as whole. This reflects the political difficulties encountered by the government's preferred city-regional approach in the Leeds and Sheffield city regions, with the latter electing a Labour mayor without agreed powers or budget in May $2018 .{ }^{57}$ The 'One Yorkshire' proposal had not at the time of writing (May 2018) gained the support of the Government, although discussions are on-going. ${ }^{58}$

The wider devolution agenda has lost momentum since 2016 with the government focusing only on those areas where devolution has stalled (the North East and Yorkshire), whilst supporting the areas with elected mayors with additional funding. For example, half of the new $£ 1.7$ billion Transforming Cities Fund for investment in transport has been devolved to the six areas with Mayors, who have the freedom to invest in their own priorities, leaving the government to allocate the remainder of the fund between all other city-regions on a competitive basis..$^{59}$

\section{Conclusions}

This article has assessed the NPh as the latest in a series of state policy reasons to the entrenched problem of uneven regional development in the UK and England more specifically. Much of the political and economic potency of the term is derived from the way it maps on to the most popular representation of regional inequality, the NorthSouth divide, aiming to boost the economic performance and competitiveness of the North. Despite the increasing focus on agglomeration economies and infrastructure investment in London and the South East over the past decade, the NPh initiative is testament to the fact that regional inequalities in England remain a political problem for the national state, generating pressures for politicians to respond. These pressures have arguably been exacerbated by the spatial unevenness of the 2008-2009 recession and subsequent recovery, and the high levels of 'leave' votes recorded in former industrial areas of the North and Midlands in the Brexit referendum. The NPh represents an important political response to the political problem of regional inequality, framed by the broader spatial rebalancing discourse developed by the Coalition Government. Driven by the former Chancellor, George Osborne, the NPh acquired strong political momentum in 2015-206 as part of a broader 'one nation' Conservative strategy to claim the middle ground of British politics and appropriate traditional Labour Party issues.

3з This article has argued that the NPh is principally a powerful spatial economic narrative that constructs the North as an economically under-performing and neglected region in need of transformation through concentrated investment in infrastructure, innovation and skills and devolution to its principal city-regions. The establishment of TfN is a key institutional expression of the NPh agenda, focusing on the development of a Northern transport strategy to link these dispersed economic capabilities. Yet TfN is a statutory advisory body rather than an executive one, leaving 
the region dependent on expenditure decisions made in Westminster. Another important effect of the NPh has been the creation of a compelling regional brand for investment attraction and trade promotion. The devolution of powers to city-regions has been folded into the NPh initiative, with the government making this conditional on local leaders' acceptance of elected 'metro mayors'. The process has proved highly uneven across the region, proceeding rapidly in Greater Manchester, Liverpool and Tees Valley, whilst it has generated prolonged political wrangling in Yorkshire and the North East. Rural areas and smaller cities and towns beyond the core city regions have been largely by-passed by the devolution process, leaving pronounced holes in the NPh. 60

The power of the NPh narrative is evident in its widespread adoption and use by regional actors and institutions, including local government leaders, LEPs, businesses and business organisations, universities and the regional media. Yet the initiative has lost political momentum and weight as an indirect result of the Brexit vote through the dismissal of Osborne and the subsequent resignation of Jim O'Neill. While the May government has periodically re-affirmed its commitment to the NPH agenda, it lacks the political prominence and leadership it enjoyed under Osborne. This is reflected in recurring criticisms of a lack of government commitment and lobbying by regional actors, for example in response to the Transport Secretary's apparent cancellation of the Trans-Pennine electrification scheme in July 2017. As such, the NPh provides a unifying, rallying call for regional interests. This helps to explain the persistence and appeal of the NPh narrative, despite reduced government commitment, alongside a lack of alternative policies from either the Conservative or Labour parties.

\section{BIBLIOGRAPHY}

Blakely, Grace, Paying for Our Progress: How Will the Northern Powerhouse be Financed and Funded? (IPPR North, 2017), pp. 16-17.

Bounds, Andrew, "Hammond hints at new money for Northern Powerhouse", The Financial Times, 4 September 2017.

Cox, Ed, "Reflections on nine years of putting the North on the political map", Infrastructure Intelligence, 4 May 2018.

http://www.infrastructure-intelligence.com/article/may-2018/reflections-nine-years-puttingnorth-political-map?utm_medium=email\&utm_source=transactional\&utm_campaign=weeklyemail

Davoudi, Simin, Turner, Roger and Garrod, Guy, A New Deal for the North: A Briefing Paper of the British Academy (London, The British Academy, 2017).

Department for Communities and Local Government, Midlands Engine Strategy 2017 (London, DCLG, 2017). 
Department for International Trade, Northern Powerhouse Investment Opportunities, undated, p. 6.

Department for Transport, Transforming Cities Fund: Call for Proposals (London, Department for Transport, 2018).

Ernst and Young, Attractiveness Survey UK, 2017, p. 14.

Gardiner, Ben, Martin, Ron, Sunley Peter and Tyler, Peter, "Spatially Unbalanced Growth in the British economy”, Journal of Economic Geography 13:6 (2013), pp. 889-928.

Gleeson, Brendan, “The Urban Age: paradox and prospect”, Urban Studies 49:5 (2012), pp. 931-942.

Haldane, Andy, 'One car, two car, red car, blue car', Speech given at Materials Processing Institute Redcar, 2 December 2016, Bank of England, London.

HM Government., Local Growth: Realising Every Place's Potential. Cm 7691 (London, HM Government, 2010).

HM Government, Northern Powerhouse Strategy, November 2016.

Hetherington, Peter, "How northern rail connections have hit the buffers", The Guardian, 1 August 2017.

Higgins, David, HS2 Plus: A Report by David Higgins (London, Department for Transport, 17 March 2014).

House of Commons Communities and Local Government Committee, Devolution in England: the Case for Local Government. First Report of Session 2014-15. HC 503 (London, The Stationery Office, 2014).

Industrial Communities Alliance, Whose Recovery? How the Upturn in Economic Growth is leaving Older Industrial Britain Behind (Barnsley, Industrial Communities Alliance, 2015).

Lee, Neil, "Powerhouse of Cards? Understanding the Northern Powerhouse", Regional Studies 51:3 (2016), pp. 478-489.

Liddle, Joyce and Ormston, Christianne, "The Legacy of the Northern Way", Local Government Studies 41:4 (2015), pp. 553-570.

Los, Bas, McCann, Philip, Springford John and Thisse, Mark, “The mismatch between local voting and the local economic consequences of Brexit", Regional Studies 51:5 (2017), pp. 786-799.

Massey, Doreen, World City (Cambridge, Polity, 2007).

Martin, Ron, "Rebalancing the spatial economy: the challenge for regional theory", Territory, Politics, Governance 3:3 (2015), pp. 235-272.

McLoughlin, Patrick and Leese, Sir Richard, foreword, The Northern Powerhouse: One Agenda, One Economy, One North, March 2015, p. 2.

National Audit Office, English Devolution Deals. HC948 (London, NAO, 30 April 2016).

National Audit Office, Progress in Setting up Combined Authorities. HC 240 (London, NAO, 3 July 2017).

Paun, Akash and Thimon Jack, Maddy, Devolution to Yorkshire: the Hole in the Northern Powerhouse? (London, Institute for Government, 2017).

Northern Powerhouse Partnership, First Report (Manchester, Northern Powerhouse Partnership, 2017). 
O’Brien, Peter, Pike, Andy and Tomaney, John, "Beyond the Northern Pitchbook”, in Mike Raco (ed.), Britain for Sale? Perspectives on the costs and benefits of foreign ownership (London, The Smith Institute, 2016).

Osborne, George, 'We need a Northern Powerhouse.' Speech at the Museum of Science and Industry, Manchester, 23 June 2014.

Osborne, George, 'Chancellor on the path to a Northern Powerhouse.' Speech at Beetham Tower, Manchester, 5 August 2014.

Osborne, George, “A rebooted Northern Powerhouse fits Theresa May's objectives”, The Financial Times, 21st August 2017.

Overman, Henry, "It's not that London is too big, but that other large UK cities are too small", 6 June 2017. http://blogs.lse.ac.uk/businessreview/2017/06/09/its-not-that-london-is-too-big-butthat-other-large-uk-cities-are-too-small/

Parker, George, "Cameron set to relaunch 'northern powerhouse' initiative", The Financial Times, 8 January 2015.

Parker, George, "Summer budget: George Osborne is a "mix of Lawson and Heseltine"', The Financial Times, 8 July 2015.

Parker, George, "Cameron set to relaunch 'northern powerhouse' initiative", The Financial Times, 8 January 2015.

Parker, George, “Theresa May sets out vision for business”, The Financial Times, 11 July 2016.

Perraudin, Frances, "No agreed power, no agreed budget: Dan Jarvis on his fight to be Sheffield mayor”, The Guardian, 23 April 2018.

Pickard, Jim and Parker, George, “Jim O’Neill resigns as Treasury minister”, The Financial Times, 23 September 2016.

Pike, Andy, Kempton, Louise, Marlow, David, O’Brien, Peter and Tomaney, John, Decentralisation: Issues, Principles and Practice (Newcastle, CURDS, Newcastle University, 2016).

Pike, A., Marlow, D., McCarthy, A., O’Brien, P. and Tomaney, J., "Local institutions and local economic development: the Local Enterprise Partnerships (LEPs) in England, 2010-“, Cambridge Journal of Regions, Economies and Societies 8:1 (2015), pp. 184-204.

Pike, Andy and Tomaney, John, "State and economy: governing uneven development in the UK" in Neil. M Coe and Andrew Jones (eds) The Economic Geography of the UK (London, Sage, 2010), pp. 91-109.

Raikes, Luke, State of the North 2017 The Millennial Powerhouse (Manchester, IPPR North, 2017).

RSA City Growth Commission, Unleashing Metro Growth: Final Recommendations of the City Growth Commission (2014), p. 9.

SQW Ltd and Cambridge Econometrics Ltd, The Northern Powerhouse Independent Economic Review, Final Executive Summary Report, 24 June 2016.

Singh, Arj, "Brokenshire must respond to pleas for Yorkshire-wide devolution", Yorkshire Post, 6 May 2018.

Topham, Gwyn, "Fury as rail electrification is scrapped by minister, but train builders roll on", The Observer, 23 July 2017.

Townsend, Alan and Champion, Tony, 'The Impact of Recession on City Regions: The British Experience, 2008-2013', Local Economy 29: 1-2 (2014), pp. 38-51. 
Transport for the North, Strategic Transport Plan: Draft for Public Consultation, January 2018.

Wakefield, Keith, Anderson, Joe, Leese, Sir Richard, Forbes Nick and Dore, Julie, One North: A Proposition for an Interconnected North, July 2014.

\section{NOTES}

1. George Osborne 'We need a Northern Powerhouse.' Speech at the Museum of Science and Industry, Manchester, 23 June 2014.

2. Department for Communities and Local Government. Midlands Engine Strategy 2017, DCLG, London.

3. Industrial Communities Alliance, Whose Recovery? How the Upturn in Economic Growth is leaving older

Industrial Britain Behind (Barnsley, Industrial Communities Alliance, 2015).

4. Ron Martin, "Rebalancing the spatial economy: the challenge for regional theory", Territory, Politics, Governance 3:3 (2015), pp. 235-272.

5. Andy Haldane, 'One car, two car, red car, blue car', Speech given at Materials Processing Institute Redcar, 2 December 2016 (London, Bank of England, 2016).

6. Ibid.

7. Doreen Massey, World City (Cambridge, Polity, 2007).

8. Alan Townsend and Tony Champion, 'The Impact of Recession on City Regions: The British Experience, 2008-2013', Local Economy 29:1-2 (2014), pp. 38-51.

9. Industrial Communities Alliance, Whose Recovery? How the Upturn in Economic Growth is leaving Older Industrial Britain Behind (Barnsley, Industrial Communities Alliance, 2015).

10. Bas Los, Philip McCann, John Springford and Mark Thisse, "The mismatch between local voting and the local economic consequences of Brexit", Regional Studies 51:5 (2017), pp. 786-799.

11. Andy Pike and John Tomaney, "State and economy: governing uneven development in the UK". In Neil M. Coe and Andrew Jones (eds.) The Economic Geography of the UK (London, Sage, 2010), pp. 91-109.

12. Ron Martin, "Rebalancing the spatial economy: the challenge for regional theory", Territory, Politics, Governance 3:3 (2015), p.253.

13. A. Pike, D. Marlow, A. McCarthy, P. O'Brien and J. Tomaney, "Local institutions and local economic development: the Local Enterprise Partnerships (LEPs) in England, 2010-", Cambridge Journal of Regions, Economies and Societies 8:1 (2015), pp. 184-204.

14. Quoted in HM Government, Local Growth: Realising Every Place's Potential. Cm 7691. (London : H M Government, 2010), p.10.

15. A. Pike, D. Marlow, A. McCarthy, P. O’Brien and J. Tomaney, op cit.

16. Ben Gardiner, Ron Martin, Peter Sunley and Peter Tyler, "Spatially Unbalanced Growth in the British economy", Journal of Economic Geography 13:6 (2013), pp. 889-928.

17. This was a pan-regional collaborative initiative between the three Northern RDAs - the North West Development Agency, One North East and Yorkshire forward - instigated by the then Deputy Prime Minister, John Prescott, which ran from 2004 to 2010. See Joyce Liddle and Christianne Ormston, "The Legacy of the Northern Way", Local Government Studies 41:4 (2015), pp. 553-570.

18. Neil Lee, "Powerhouse of Cards? Understanding the 'Northern Powerhouse", Regional Studies, 51:3 (2016), pp. 478-489.

19. SQW Ltd and Cambridge Econometrics Ltd, The Northern Powerhouse Independent Economic Review. Final Executive Summary Report, 24 June 2016; HM Government, Northern Powerhouse 
Strategy. November 2016; Northern Powerhouse Partnership: First Report. 2017. Northern Powerhouse Partnership, Manchester.

20. Brendan Gleeson, "The Urban Age: paradox and prospect”, Urban Studies 49:5 (2012), pp. 931-942.

21. Henry Overman, "It's not that London is too big, but that other large UK cities are too small", 6 June 2017. http://blogs.lse.ac.uk/businessreview/2017/06/09/its-not-that-london-is-too-bigbut-that-other-large-uk-cities-are-too-small/ Last accessed 18 June 2017.

22. RSA City Growth Commission. Unleashing Metro Growth: Final Recommendations of the City Growth Commission. 2014, p. 9.

23. George Osborne 'We need a Northern Powerhouse.' Speech at the Museum of Science and Industry, Manchester, 23 June 2014; George Osborne 'Chancellor on the path to a Northern Powerhouse.' Speech at Beetham Tower, Manchester, 5 August 2014.

24. George Parker, "Cameron set to relaunch 'northern powerhouse' initiative", The Financial Times, 8 January 2015.

25. George Parker, "Summer budget: George Osborne is a "mix of Lawson and Heseltine", The Financial Times, 8 July 2015.

26. Alan Townsend and Tony Champion, op. cit.

27. Ben Gardiner, Ron Martin, Peter Sunley and Peter Tyler, op. cit.

28. Grace Blakely, Paying for Our Progress: How Will the Northern Powerhouse be Financed and Funded? (IPPR North, 2017), p. 16-17.

29. Ibid.

30. George Parker, "Theresa May sets out vision for business", The Financial Times, 11 July 2016.

31. Jim Pickard and George Parker, “Jim O'Neill resigns as Treasury minister”, The Financial Times, 23 September 2016.

32. HM Government, Northern Powerhouse Strategy, November 2016.

33. George Osborne, "A rebooted Northern Powerhouse fits Theresa May's objectives", The Financial Times, $21^{\text {st }}$ August 2017.

34. Neil Lee, op. cit.

35. Patrick McLoughlin and Sir Richard Leese, foreword, The Northern Powerhouse: One Agenda, One Economy, One North, March 2015, p. 2.

36. David Higgins, HS2 Plus: A Report by David Higgins, London, Department for Transport, p. 10, 17 March 2014.

37. Neil Lee, op. cit, p. 8-9.

38. Ibid.

39. Keith Wakefield, Joe Anderson, Sir Richard Leese, Nick Forbes and Julie Dore, One North: A Proposition for an Interconnected North, July 2014.

40. Transport for the North, Strategic Transport Plan: Draft for Public Consultation. January 2018.

41. Ed Cox, "Reflections on nine years of putting the North on the political map", Infrastructure Intelligence, 2018.

42. Transport for the North, op. cit.

43. Peter Hetherington, "How northern rail connections have hit the buffers", The Guardian, 1 August 2017; Gwyn Topham, "Fury as rail electrification is scrapped by minister, but train builders roll on", The Observer, 23 July 2017.

44. https://you.38degrees.org.uk/petitions/crossrail-north-now

45. Andy Bounds, "Hammond hints at new money for Northern Powerhouse", The Financial Times, 4 September 2017.

46. Department for International Trade, Northern Powerhouse Investment Opportunities, undated, p. 6. 
47. Peter O'Brien, Andy Pike and John Tomaney, "Beyond the Northern Pitchbook" in Mike Raco (ed.), Britain for Sale? Perspectives on the costs and benefits of foreign ownership (London, The Smith Institute, 2016).

48. Senior policy-maker, author's interviews, September 2017.

49. Peter O'Brien, Andy Pike and John Tomaney, op. cit.

50. Government official, author's interviews, September 2017.

51. Ernst and Young, Attractiveness Survey UK, 2017, p.14.

52. Andy Pike, Louise Kempton, David Marlow, Peter O'Brien and John Tomaney, Decentralisation: Issues, Principles and Practice, (Newcastle, CURDS, Newcastle University, 2016).

53. House of Commons Communities and Local Government Committee, Devolution in England: the Case for Local Government. First Report of Session 2014-15. HC 503 (London, The Stationery Office. 2014).

54. Neil Lee, op. cit, p. 5.

55. National Audit Office, Progress in Setting up Combined Authorities. HC 240 (London, NAO, 3 July 2017).

56. National Audit Office, English Devolution Deals. HC948 (London, NAO, 30 April 2016).

57. Akash Paun and Maddy Thimon Jack, Devolution to Yorkshire: the Hole in the Northern Powerhouse? (London, Institute for Government, 2017); Frances Perraudin, "No agreed power, no agreed budget: Dan Jarvis on his fight to be Sheffield mayor", The Guardian, 23 April 2018.

58. Arj Singh, "Brokenshire must respond to pleas for Yorkshire-wide devolution", Yorkshire Post, 6 May 2018.

59. Department for Transport, Transforming Cities Fund: Call for Proposals (London, Department for Transport, 2018).

60. Paun and Jack, op. cit; Simin Davoudi, Roger Turner and Guy Garrod, A New Deal for the North: A Briefing Paper of the British Academy (London, The British Academy, 2017).

\section{ABSTRACTS}

The Northern Powerhouse (NPh) is a UK government initiative for increasing the economic competiveness of the North of England launched by the former Chancellor, George Osborne in 2014. Informed by the new urban economics and the importance of agglomeration and urban scale and density in fostering competitiveness, the NPh sought to pool the strengths of the Northern core cites, principally Manchester, Leeds, Liverpool and Sheffield, as a kind of transformative urban counter-weight to London. This article aims to assess the nature and wider significance of the NPh, considering its evolution and impact since 2014. It argues that the NPh is a spatial economic narrative that has gained the support of a wide range of Northern interests, but that its coherence and implementation has been undermined by a lack of national government commitment and leadership since 2016.

La Northern Powerhouse est une initiative du gouvernement britannique visant à accroître la compétitivité économique du nord de l'Angleterre. Lancée par l'ancien Ministre des finances, George Osborne en 2014, elle se base sur les principes de la Nouvelle Economie Urbaine et donc sur l'importance des effets d'agglomération, d'échelle et de densité urbaine en vue de promouvoir la compétitivité. En mettant en commun les forces des villes clés du Nord (principalement Manchester, Leeds, Liverpool et Sheffield), la Northern Powerhouse a cherché à 
susciter une dynamique urbaine transformatrice en mesure de contrebalancer le poids de Londres. L'article analyse en quoi consiste la Northern Powerhouse, en considérant son évolution et son impact depuis 2014. Il avance que la Northern Powerhouse constitue avant tout un discours sur l'économie spatiale ayant rallié le soutien d'un grand nombre d'intêrêts au nord de l'Angleterre mais dont la cohérence et la mise en oeuvre ont été mises à mal par un manque d'engagement et de leadership du gouvernement britannique depuis 2016.

\section{INDEX}

Mots-clés: Northern Powerhouse, inégalités régionales, agglomération, rééquilibrage spatial, transport, dévolution

Keywords: Northern Powerhouse, regional inequality, agglomeration, spatial rebalancing, transport, devolution

\section{AUTHOR}

\section{DANNY MACKINNON}

Centre for Urban and Regional Development Studies (CURDS), Newcastle University 